\title{
Variabilidade genética de acessos de araçazeiro e goiabeira suscetíveis e resistentes a Meloidogyne enterolobii
}

\author{
Genetic variability of araça and guava accessions susceptible and resistant Meloidogyne enterolobii
}

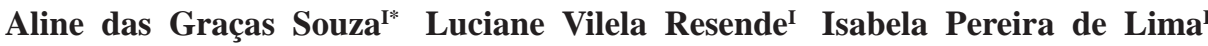 \\ Rosimar Musser dos Santos"II Nilton Nagib Jorge Chalfun ${ }^{\mathrm{I}}$
}

\section{RESUMO}

A goiabeira representa uma importante atividade frutícola no Brasil, com mercado cada vez maior. Porém, desde 1989 vêm sendo relatados severos danos à cultura, causados pelo nematóide Meloidogyne enterolobii. Uma das alternativas para solucionar esse problema é a utilização de porta-enxertos com resistência a este patógeno. Este trabalho teve por objetivo a caracterização molecular, com marcadores RAPD, de acessos de Psidium testados quanto à resistência a $\mathbf{M}$. enterolobii $e$ quanto à compatibilidade como porta-enxertos para as goiabeiras comerciais. Foram testados 30 primers, dos quais 19 forneceram resultados nítidos para a amplificação. Foram gerados 163 fragmentos, dos quais 86 polimórficos (63,0\%). Em média, cada iniciador produziu 8,6 fragmentos, dos quais 5,4 apresentaram polimorfismo. A análise de agrupamento foi realizada por espécie, os acessos de Psidium sp apresentaram a formação de dois grupos, um formado pelo acesso A-UFLA e o segundo subdividido em quatro subgrupos, sendo os acessos com maiores distâncias genéticas A-Ufla, resistente a M. enterolobii, A-Ufla4 e A-Ufla5, ambos suscetíveis ao nematoide em questão, todos coletados em Lavras-MG, com similaridade aproximada de 66\%. Na análise de agrupamento, dos treze acessos de P.cattleyanum, foi possível constatar a formação de dois grandes grupos. Um formado por três acessos suscetíveis a M. enterolobii (A-20.2, A-10.1 e A-9.2) e outro grupo formado por dez acessos. Os acessos se agruparam, conforme a região de origem, em seis grupos, sendo que o mais divergente é originário da região de Lavras - MG, com 0,65 de similaridade, onde as distâncias genéticas variaram de 0,88 a 0,65. Dos treze acessos de $\boldsymbol{P}$. guineense, todos suscetíveis a $\mathbf{M}$. enterolobii, sendo 12 oriundos de Recife e um de Pelotas (A-14.1) e agruparam-se em dois grupos com similaridades variando de 0,59 a 0,83. Quanto ao estudo de diversidade entre os acessos de goiabeiras, a maior distância genética foi detectada entre o acesso G-Ufla com 0,71 Lavras-MG.

Palavras-chave: resistência de plantas a doenças, nematoide de galha, marcadores genéticos.

\section{ABSTRACT}

Guava culture stands for an important fruit-growing business in Brazil, with a greater and greater market. But, since 1989 severe damages to the culture caused by the nematode Meloidogyne enterolobii, have been reported. One the alternatives to solve this problem is the use of rootstocks with resistance to this nematode. This research aimed at the molecular characterization, with RAPD markers, of Psidium accessions susceptible to be utilized as rootstocks for the commercial guava trees. 30 primers were tested, from which 19 supplied distinct results for the amplification. The primers generated 163 polymorphic marks, resulting into a mean of 8,6 polymorphic bands per primer. The cluster analysis was performed per species, the accessions of Psidium sp presented the formation of two groups, one formed by A-UFLA accession and the other subdivided into four subgroups, that is, the accession with increased genetic distances, A-Ufla, resistant to M. enterolobii, A-Ufla4 and A-Ufla5, both susceptible to the nematode in issue, all collected in Lavras-MG with a similarity of about $66 \%$. In the cluster analysis of the thirteen accessions of P.cattleyanum, it was possible to found the formation of two great groups. One made up by three accessions susceptible to M. enterolobii (A-20.2, A-10.1 and A-9.2) and the other group formed by ten accessions. The accessions grouped together according to the region of origin in six groups, the most divergent being that native to region of Lavras - MG, with 0.65 of similarity, where the genetic distances ranged from 0.88 to 0.65 . The thirteen accessions of P. guineense, all susceptible to M. enterolobii, namely, 12 coming from Recife and one proceeding from Pelotas (A-14.1), grouped themselves together and two groups with similarity ranging from 0.59 to 0.83 . As to the diversity study among the guava tree accessions, the greatest genetic distances were detected between the accessions G.P.S and G-Ufla with 0,71 Lavras-MG.

Key words: plant resistance to diseases, root-not nematode, genetic markers.

'Departamento de Agricultura, Universidade Federal de Lavras (UFLA), Campus Universitário, 37200-000, Lavras, MG, Brasil. E-mail: alineufla@hotmail.com.br.*Autor para correspondência.

"Departamento de Fitotecnia, Universidade Federal Rural de Pernambuco (UFRPE), Campus Universitário, Recife, PE, Brasil.

$$
\begin{array}{rrr}
\text { Recebido 26.10.11 } & \text { Aprovado 14.12.13 } & \text { Devolvido pelo autor 14.03.14 } \\
\text { CR-6237 } &
\end{array}
$$




\section{INTRODUÇÃO}

O Brasil possui grandes áreas com condições edafoclimáticas favoráveis à produção comercial de goiaba, o que é relevante, não apenas pelo valor nutritivo da fruta, mas também pela perspectiva que representa no incremento da produção agrícola, na ampliação da atividade industrial e no potencial de exportação (ROZANE \& COUTO, 2003). Em 1988, Meloidogyne enterolobii Rammah \& Hirschmann, foi assinalado pela primeira vez no Brasil, em Petrolina (PE), Curaçá e Maniçoba (BA), causando danos severos em plantios comerciais de goiabeira $(\boldsymbol{P}$. guajava L.) (CARNEIRO et al., 2001).

Esse nematoide de galha é altamente agressivo e representa séria ameaça à cultura da goiaba e a outras culturas do agronegócio nacional (SOUZA et al., 2006). TORRES et al. (2004) constataram que cerca de $70 \%$ das goiabeiras da região do Vale do São Francisco (Brasil) já morreram devido ao ataque do nematoide. Em casos mais graves, pomares adultos têm sido erradicados aos quatro anos (GOMES et al., 2008). No manejo integrado de nematoide, o uso de cultivares resistentes é uma alternativa vantajosa e econômica, comparado ao emprego de nematicidas. Espécies pertencentes à família Myrtaceae, com resistência a $\boldsymbol{M}$. enterolobii, possibilitariam seu uso como porta-enxerto para as variedades comerciais de goiabeira.

A existência de grande número de materiais geneticamente diferentes, mas que mantêm alguma afinidade morfofisiológica, aumenta a chance de haver compatibilidade na enxertia entre diferentes espécies de Psidium (HARTMAN et al., 1997). Portanto, é imprescindível a busca por materiais resistentes dentro da família em estudo e o acesso da viabilidade genética do uso desses materiais como porta-enxertos.

Atualmente, os programas de melhoramento genético têm utilizado a associação de técnicas clássicas a ferramentas biotecnológicas, com o objetivo de aumentar a eficiência de seleção e caracterização de germoplasmas e a maximização dos ganhos genéticos, permitindo aos melhoristas o acesso e a seleção da variabilidade no DNA. Uma das principais vantagens da utilização destes é propiciar a redução do tempo para identificação da diversidade genética entre os indivíduos trabalhados (XAVIER et al., 2005). Um dos marcadores moleculares utilizados é o RAPD (amplificação arbitrária polimórfica de DNA) por ser uma técnica rápida e de custo relativamente baixo, porém com potencial informativo (AREIAS et al., 2006). Essa técnica pode ser utilizada para análise de diversidade genética e caracterização de germoplasma, como PADILHA-RAMÍREZ et al. (2002), que empregaram os marcadores RAPD para diferenciação molecular de acessos do banco de germoplasma de P. guajava L. do México, e constataram baixa variabilidade genotípica entre os acessos.

Este trabalho teve por objetivo a caracterização molecular de acessos de goiabeira e araçazeiro avaliados em trabalhos prévios de reação a M. enterolobii, passíveis de serem utilizados como porta-enxertos para cultivares comerciais de goiabeira.

\section{MATERIAL E MÉTODOS}

Os materiais foram coletados a partir de 35 acessos de araçazeiro e 5 acessos de goiabeira, oriundos de regiões próximas ao município de Lavras (MG), sendo propagados por sementes, mantidos em casa de vegetação no Setor de Hidroponia do Departamento de Ciência do Solo, localizado no município de Lavras, MG, o clima é do tipo Cwb. No presente estudo, foram avaliados cinco acessos de goiabeira e 35 acessos de araçazeiro, já submetidos à reação a $\boldsymbol{M}$. enterolobii e classificados como suscetíveis e resistentes (Tabela 1).

Extração e amplificação de DNA

O preparo das amostras foi realizado no Laboratório de Eletroforese do setor de Sementes do Departamento de Agricultura da Universidade Federal de Lavras. Cerca de 50mg de folhas jovens, sadias, coletadas dos cinco acessos de goiabeiras e 35 de araçazeiro foram maceradas em $\mathrm{N}$ líquido até a obtenção de pó fino, em seguida transferido para tubos Eppendorf de 2,0mL. O DNA das amostras foi extraído conforme o protocolo DOYLE \& DOYLE (1990), para serem genotipadas com marcadores RAPD. Foram testados 30 primers e selecionados 19 (Tabela 2).

As reações de amplificação dos fragmentos de DNA (PCR) foram feitas em termociclador Perkin Elmer, Modelo Gene Amp PCR System 2400, num meio com volume final de $10 \mu \mathrm{L}$, contendo: $1,59 \mu 1$ de água miliq, $1,3 \mu 1$ de tampão $(1 \mathrm{x}), 0,65 \mu 1 \mathrm{MgCl}_{2}$ $(2,5 \mathrm{mM}), 0,26 \mu \mathrm{l}$ de dNTPmix $(0,2 \mathrm{mM}), 5,0 \mu \mathrm{l} \mathrm{de}$ primer $(25 \mathrm{ng}), 0,2 \mu \mathrm{l}$ da Taq DNA polimerase (1U) e $1 \mu 1$ de DNA (20ng). Foi seguida a metodologia de WILLIAMS et al. (1993).

O programa de amplificação consistiu em $95^{\circ} \mathrm{C}$ de temperatura inicial por $2 \mathrm{~min}, 45$ ciclos de amplificação a $94^{\circ} \mathrm{C}$ por $45 \mathrm{seg} ; 42^{\circ} \mathrm{C}$ por $1 \mathrm{~min} ; 72^{\circ} \mathrm{C}$ por $2 \mathrm{~min}$ (FILHO, et al., 2010). Após as reações, os produtos de amplificação do DNA foram separados em gel de agarose 1,5\%, contendo Syber Goold e 
Tabela 1 - Acessos de goiabeira e araçazeiro resistente e suscetível ao Meloidogyneenterolobii utilizados no experimento de caracterização molecular, visando à diversidade genética.

\begin{tabular}{|c|c|c|c|c|}
\hline Acesso & Procedência & Nome comum & Nome científico & Reação \\
\hline A-Roxo-u & Carrancas-MG & Araçazeiro & Psidium sp. & $\mathrm{R}$ \\
\hline A-Ufla5 & Lavras-MG & Araçazeiro & Psidium sp. & $\mathrm{S}$ \\
\hline A-Ufla1 & Lavras-MG & Araçazeiro & Psidium $s p$. & $\mathrm{S}$ \\
\hline A-Ufla4 & Lavras-MG & Araçazeiro & Psidium sp. & $\mathrm{S}$ \\
\hline A- lu1 & Itumirim-MG & Araçazeiro & Psidium sp. & $\mathrm{R}$ \\
\hline A- lu2 & Itumirim-MG & Araçazeiro & Psidium $s p$ & $\mathrm{R}$ \\
\hline A- lu3 & Itumirim-MG & Araçazeiro & Psidium $s p$ & $\mathrm{R}$ \\
\hline G-Amar & Patos de Minas-MG & Goiabeira-amarela & P. guajava & $\mathrm{S}$ \\
\hline A-Roxo-c & Carrancas-MG & Araçazeiro & Psidium $s p$. & $\mathrm{R}$ \\
\hline A-16.2 & Recife-PE & Araçazeiro & P. guineense & $\mathrm{S}$ \\
\hline A-14.1 & Pelotas-RS & Araçazeiro & P. guineense & $\mathrm{S}$ \\
\hline A-Ufla & Lavras-MG & Araçazeiro & Psidium sp. & $\mathrm{R}$ \\
\hline A-14.3 & Recife-PE & Araçazeiro & P. guineense & $\mathrm{S}$ \\
\hline A-Boi & Recife-PE & Araçazeiro & P. cattleyanum & $\mathrm{S}$ \\
\hline A-18.4 & Recife-PE & Araçazeiro & P. guineense & $\mathrm{S}$ \\
\hline A-10.2 & Recife-PE & Araçazeiro & P. guineense & $\mathrm{S}$ \\
\hline A-Amar & Carrancas-MG & Araçazeiro & P. cattleyanum & $\mathrm{R}$ \\
\hline A-30 & Recife-PE & Araçazeiro & P. cattleyanum & $\mathrm{R}$ \\
\hline A.S.V & Recife-PE & Araçazeiro & P. cattleyanum & $\mathrm{R}$ \\
\hline A-26.2 & Recife-PE & Araçazeiro & P. guineense & $\mathrm{S}$ \\
\hline A-19.2 & Recife-PE & Araçazeiro & P. guineense & $\mathrm{S}$ \\
\hline A-25.4 & Recife-PE & Araçazeiro & P. guineense & $\mathrm{S}$ \\
\hline A-23 & Recife-PE & Araçazeiro & P. cattleyanum & $\mathrm{R}$ \\
\hline A-30.4 & Recife-PE & Araçazeiro & P. cattleyanum & $\mathrm{R}$ \\
\hline G-Ufla & Lavras-MG & Goiabeira-Ufla & P. guajava & $\mathrm{S}$ \\
\hline G.P.S & Carrancas-MG & Goiabeira Pedro-Sato & P. guajava & $\mathrm{S}$ \\
\hline G.C.F & Carrancas-MG & Goiabeira- Carrancas & P. guajava & $\mathrm{S}$ \\
\hline A-R.S & Pelotas-RS & Araçazeiro & P. cattleyanum & $\mathrm{R}$ \\
\hline A-19.4 & Recife-PE & Araçazeiro & P. guineense & $\mathrm{S}$ \\
\hline A-23.1 & Recife-PE & Araçazeiro & P. guineense & $\mathrm{S}$ \\
\hline A-20.1 & Recife-PE & Araçazeiro & P. guineense & $\mathrm{S}$ \\
\hline A-20.4 & Recife-PE & Araçazeiro & P. guineense & $\mathrm{S}$ \\
\hline A-17.2 & Recife-PE & Araçazeiro & P. guineense & $\mathrm{S}$ \\
\hline A-Pasto & Itumirim-MG & Araçazeiro & P. cattleyanum & $\mathrm{S}$ \\
\hline G.Roxa & Carrancas-MG & Goiabeira-roxa & P. guajava & $\mathrm{S}$ \\
\hline A-30.3 & Itumirim-MG & Araçazeiro & P. cattleyanum & $\mathrm{R}$ \\
\hline A-R.E & Ingaí-MG & Araçazeiro & P. cattleyanum & M.R \\
\hline A-20.2 & Recife-PE & Araçazeiro & P. cattleyanum & $\mathrm{S}$ \\
\hline A-10.1 & Recife-PE & Araçazeiro & P. cattleyanum & $\mathrm{S}$ \\
\hline A-9.2 & Lavras-MG & Araçazeiro & P. cattleyanum & $\mathrm{S}$ \\
\hline
\end{tabular}

submetidos à eletroforese em tampão TBE 1X. Após a amplificação, os fragmentos foram visualizados por meio de eletroforese em gel. Para efeito da comparação de tamanho dos fragmentos amplificados, foi utilizado como padrão o DNA Ladder $100 \mathrm{bp}$, adquirido da INVITROGEN Life Technologies e visualizados sob luz UV.

Os produtos da amplificação visualizados no gel, produzidos por cada primer, foram utilizados na elaboração de uma matriz de similaridade genética, por meio do registro da presença (1) e da ausência (0) de bandas no perfil eletroforético de cada genótipo, e serviu para a diferenciação dos acessos. Com auxílio do programa NTSYS, versão 2.1 (ROHLF, 2000), os coeficientes de similaridade de Coincidência Simples entre os acessos foram usados para a construção do dendrograma, pelo método UPGMA (Unweighted Pair-Group Methodwith Arithmetic Averages), adotando a rotina SAHN (Sequential Agglomerative, Hierarchicaland Nested Clustering). 
Tabela 2 -Produtos resultantes das reações de amplificação de DNA de acessos de Psidium, com base nos marcadores RAPD.

\begin{tabular}{|c|c|c|c|c|}
\hline \multirow{2}{*}{$\begin{array}{l}\text { Nome do Primer } \\
\text { Operon }\end{array}$} & \multirow[b]{2}{*}{ Sequência 3'- 5' } & \multirow[b]{2}{*}{ Total } & \multirow[b]{2}{*}{ Bandas polimórficas } & \multirow[b]{2}{*}{$\%$ de bandas polimórficas } \\
\hline & & & & \\
\hline OPAH 03 & GGT TAC TGC C & 10 & 04 & 40 \\
\hline OPAH 04 & CTC CCC AGA C & 14 & 07 & 50 \\
\hline OPAH 11 & TGA GTC CGCA & 14 & 10 & 71,0 \\
\hline OPAH 12 & CTACAGCGAG & 12 & 05 & 42,0 \\
\hline OPA 10 & GTG ATC GCA G & 11 & 08 & 72,0 \\
\hline OPA12 & TCG GCG ATA G & 9 & 05 & 55,5 \\
\hline UBC 132 & AGG GAT CTC C & 9 & 05 & 55,0 \\
\hline UBC135 & AAG CTG CGA G & 9 & 06 & 66,6 \\
\hline UBC153 & GAG TCA CGA G & 8 & 06 & 62,5 \\
\hline UBC 155 & CTG GCG GCT G & 5 & 00 & 00 \\
\hline BR65 & TCG GCG ATAG & 5 & 02 & 40,0 \\
\hline PC11 & CAG CAC CCA C & 10 & 04 & 40,0 \\
\hline PRIMER 1 & CCT GGG TGG A & 10 & 08 & 80,0 \\
\hline PRIMER 2 & CCT GGG TGG A & 6 & 00 & 00 \\
\hline PRIMER 3 & CCT GGG TCC A & 9 & 06 & 66,0 \\
\hline PRIMER 5 & GAA ACA GCG G & 5 & 00 & 00 \\
\hline PRIMER 6 & GCC CGG TTT A & 7 & 04 & 57,0 \\
\hline PRIMER 7 & GGA GCC CAC & 5 & 03 & 60,0 \\
\hline PRIMER 15 & CTA CCC GTG C & 5 & 03 & 60,0 \\
\hline Totais & & 163 & 86 & \\
\hline Médias & & 8,6 & 5,4 & 63,0 \\
\hline
\end{tabular}

\section{RESULTADOS E DISCUSSÃO}

Dentre os primers estudados, UBC155, PRIMER 2, PRIMER 5 geraram produtos monomórficos, e os fragmentos produzidos por $\mathrm{OPAH}$ 03, OPAH 04, OPAH 11, OPAH 12, OPA 10 , OPA 12 , UBC 132, UBC135, UBC153, BR65, PC11, PRIMER 1, PRIMER 3, PRIMER 6, PRIMER 7 e PRIMER 15 apresentaram polimorfismo (Tabela 2). Foram gerados 163 fragmentos, dos quais 86 polimórficos $(63,0 \%)$. Em média, cada iniciador produziu 8,6 fragmentos, dos quais 5,4 apresentaram polimorfismo. Em estudo de diversidade genética em goiabeira, realizado por PADILLA-RAMÍREZ et al. (2002), no México, foi observado pelos autores um nível de $60 \%$ de polimorfismo, resultado este inferior ao encontrado neste trabalho.

A análise de agrupamento foi realizada por espécie, os acessos de Psidium,sp apresentaram a formação de dois grupos, um formado pelo acesso A-Ufla e o segundo subdividido em quatro subgrupos (Figura 1).

O primeiro subgrupo foi formado pelos acessos A-roxo-u, A-roxo-c e A-Ufla1, sendo resistentes a $\boldsymbol{M}$. enterolobii e os acessos A-lu1, A-lu2 e A-lu3, todos apresentaram-se resistentes a $M$. enterolobii, formaram o segundo subgrupo do dendrograma, mostrando grande similaridade genética, sendo que os acessos A-lu2 e A-lu3 com similaridade maior entre si. Em contrapartida, os materiais que apresentaram as maiores distâncias genéticas foram os acessos A-Ufla, resistente a M. enterolobii, A-Ufla4 (subgrupo três) e A-Ufla5 (subgrupo quatro), ambos suscetíveis ao nematoide em questão, com uma similaridade aproximada de $66 \%$. Dessa forma, evidencia-se que estes acessos são genótipos diferenciados e apresentaram respostas também diferenciadas em relação à resistência ao nematoide. Segundo ROTILI et al. (2012), grupos formados por apenas um indivíduo apontam na direção de que tais indivíduos sejam mais divergentes em relação aos demais, como é observado neste trabalho (A-Ufla).

$\mathrm{Na}$ análise de agrupamento dos treze acessos de $\boldsymbol{P}$. cattleaynum (Figura 2), foi possível constatar a formação de dois grandes grupos. Um formado por três acessos suscetíveis a $\mathbf{M}$. enterolobii (A-20.2, A-10.1 e A-9.2) e outro grupo formado por dez acessos, em que A-Pasto (suscetível), A-30.3 (resistente), A.R.E (moderadamente resistente), sendo que A-Pasto e A-30.3 com 0,87 mostraram similaridade maior entre si do que em relação ao A.R.E com 0,82. Dessa forma, evidencia-se que estes materiais, apesar da formação de subgrupos, 


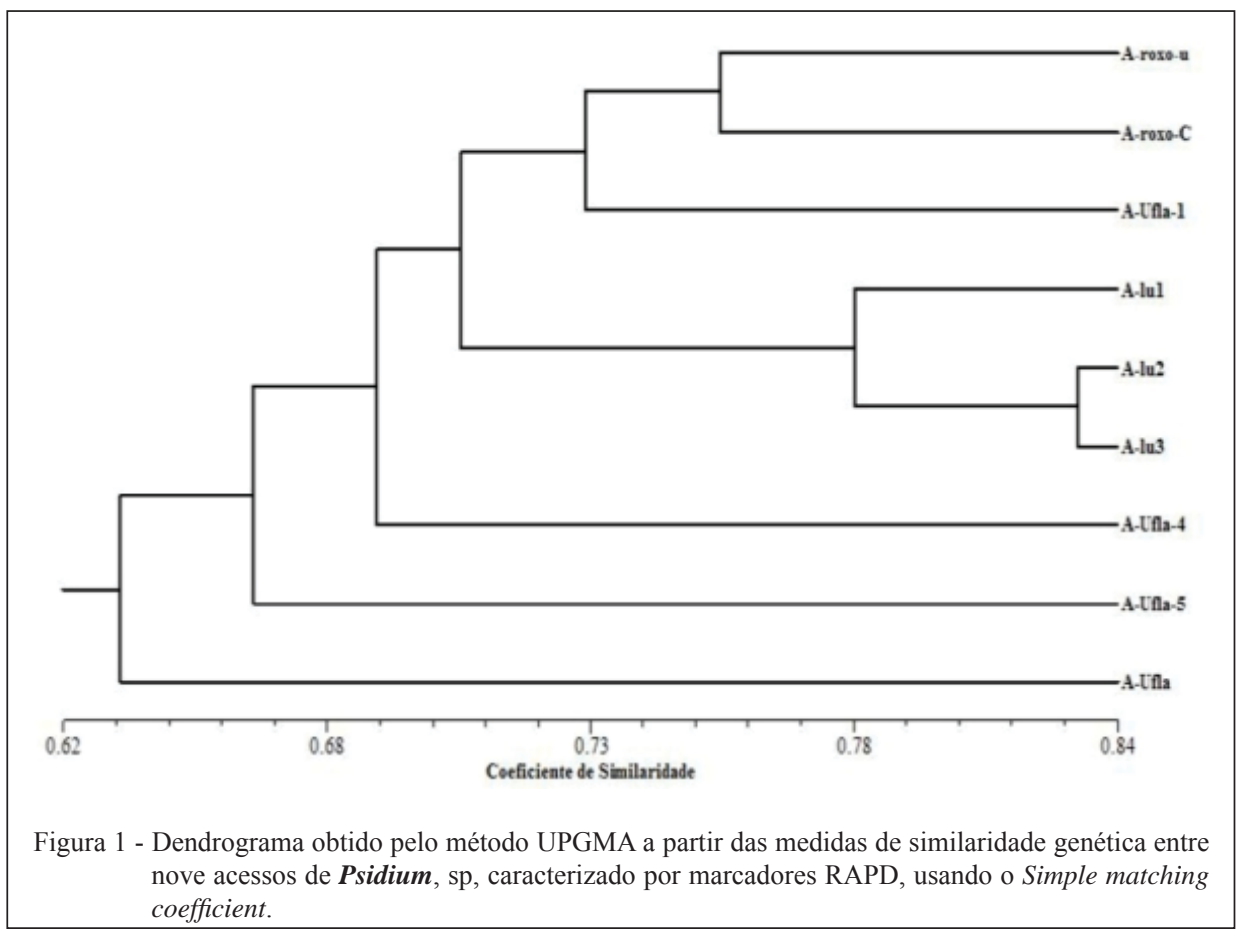

apresentam uma distância genética menor, isto pode ter ocorrido devido à região de origem.

Considerando $\boldsymbol{P}$. cattleyanum, os acessos se agruparam conforme a região de origem em seis grupos, sendo que o acesso mais divergente foi
(A- 9.2) com 0,70 evidenciando maior diversidade genética. Neste estudo, as distâncias genéticas variaram de 0,88 a 0.65 (Figura 2). Pode-se observar que o acesso (A-R.S) posicionou-se no mesmo ramo do acesso (A-Amar), com similaridade entre ambos

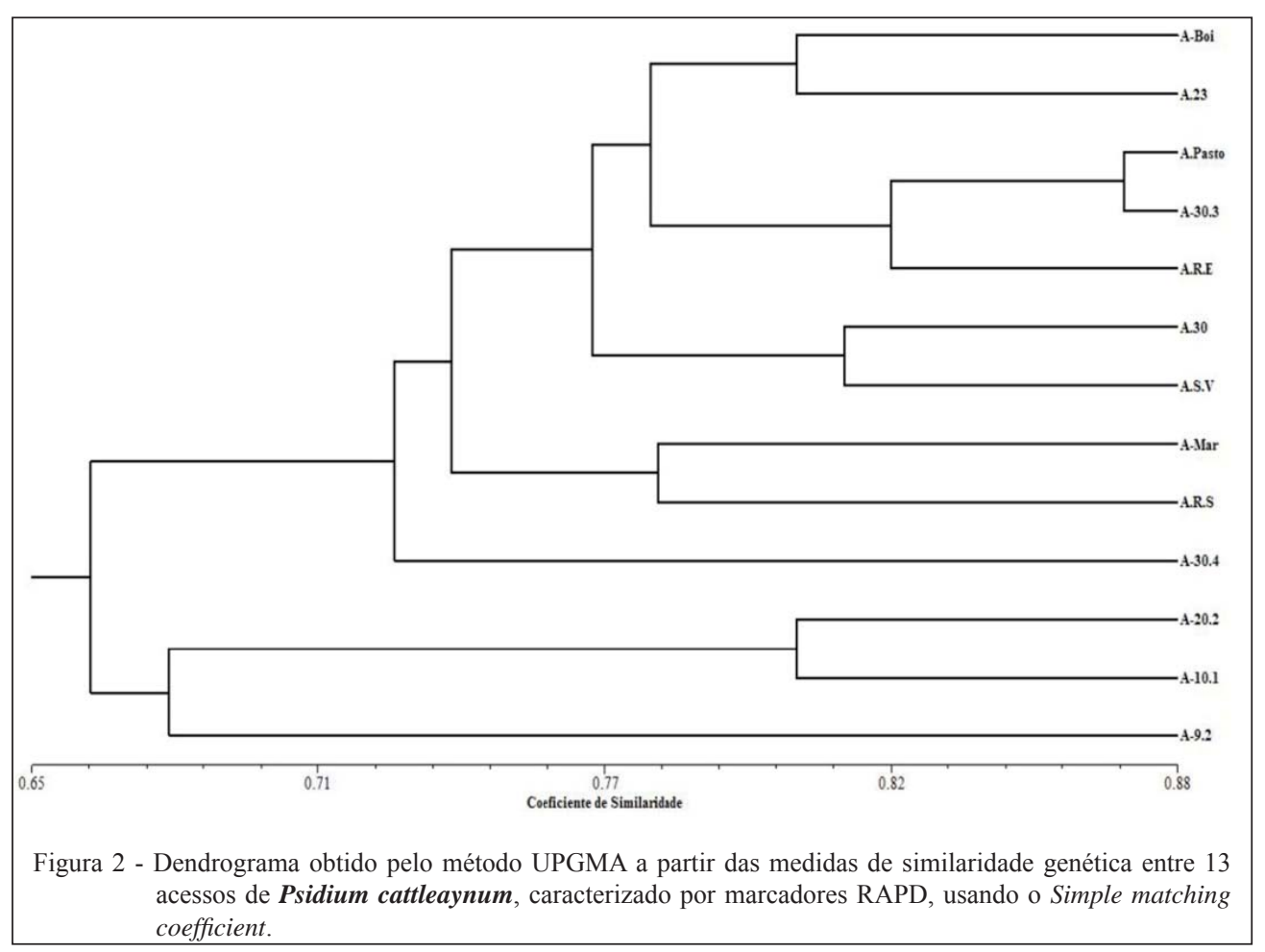

Ciência Rural, v.44, n.5, mai, 2014. 
de 0,75. Já os acessos (A-Pasto e A-30.3) mostraram uma similaridade de 0,87 .

Observou-se também uma mistura genotípica entre os acessos de $\boldsymbol{P}$. cattleyanum, independentemente do Estado de origem. A esse respeito, UPADHYAY; MURTY (1970) afirmam que a deriva genética e a seleção, em diferentes ambientes, podem causar maior divergência que a distância geográfica.

Os treze acessos de $\boldsymbol{P}$. guineense, (Figura 3) todos suscetíveis a M. enterolobii, sendo 12 oriundos de Recife e um oriundo de Pelotas (A-14.1), agruparam-se em arranjos com similaridades variando de 0,59 a 0,83. O acesso proveniente de Pelotas-RS foi o que apresentou maior diferença: agrupou-se separadamente dos demais com similaridade de 0,59, apresentando a maior distância genética. Os acessos A-14.3 e A-26.2 com similaridade de 0,83 foram os mais próximos. Embora a maioria dos acessos seja proveniente de um mesmo local, estes apresentaram uma variabilidade genética considerável.

Em estudo de diversidade genética em goiabeira, realizado por PADILLA-RAMÍREZ et al. (2002), utilizando marcadores moleculares (RAPD), eles observaram que, na região de Calvillo-Cañones (México), há reduzida variabilidade genética, pois nos materiais avaliados encontrou-se uma similaridade genética da ordem de $88 \%$.
Os resultados aqui encontrados demonstram que, entre os materiais estudados, existe uma variabilidade genética considerável, fato este que proporciona aos melhoristas materiais com grande potencial para a obtenção de genótipos superiores. Os maiores valores de similaridade, ou seja, os materiais mais semelhantes foram os acessos G-Amar e G.C.F. com 0,82, (Figura 4). Em contrapartida, o acesso que apresentou a maior distância genética, quando comparado aos demais, foi G-Ufla, com 0,63.

$\mathrm{O}$ alto grau de polimorfismo detectado pode estar relacionado ao sistema de polinização mista da goiabeira e ao fato de a cultura possuir uma taxa maior de fecundação cruzada, quando comparada à autofecundação (ALVES \& FREITAS, 2007), ou ainda à intensa utilização de sementes na produção de mudas, o que acarretaria em ampla variabilidade genética. Segundo OLIVEIRA et al. (2007), há tendência em germoplasma de plantas arbóreas e arbustivas, alógamas ou autógamas, com alta taxa de alogamia, de apresentarem alto grau de polimorfismo.

Fontes de resistência a $\boldsymbol{M}$. enterolobii foram encontradas nos acessos nativos de $\boldsymbol{P}$. cattleyanum, pertencentes às regiões de Carrancas - MG, Itumirim -MG e Lavras - MG, e nos acessos de Psidium sp, A-lu1, A-lu2 e A-lu3 de Araçazeiro Amarelo (Tabela 1).

A similaridade média encontrada neste trabalho, de $71 \%$, mostrou que os acessos apresentam

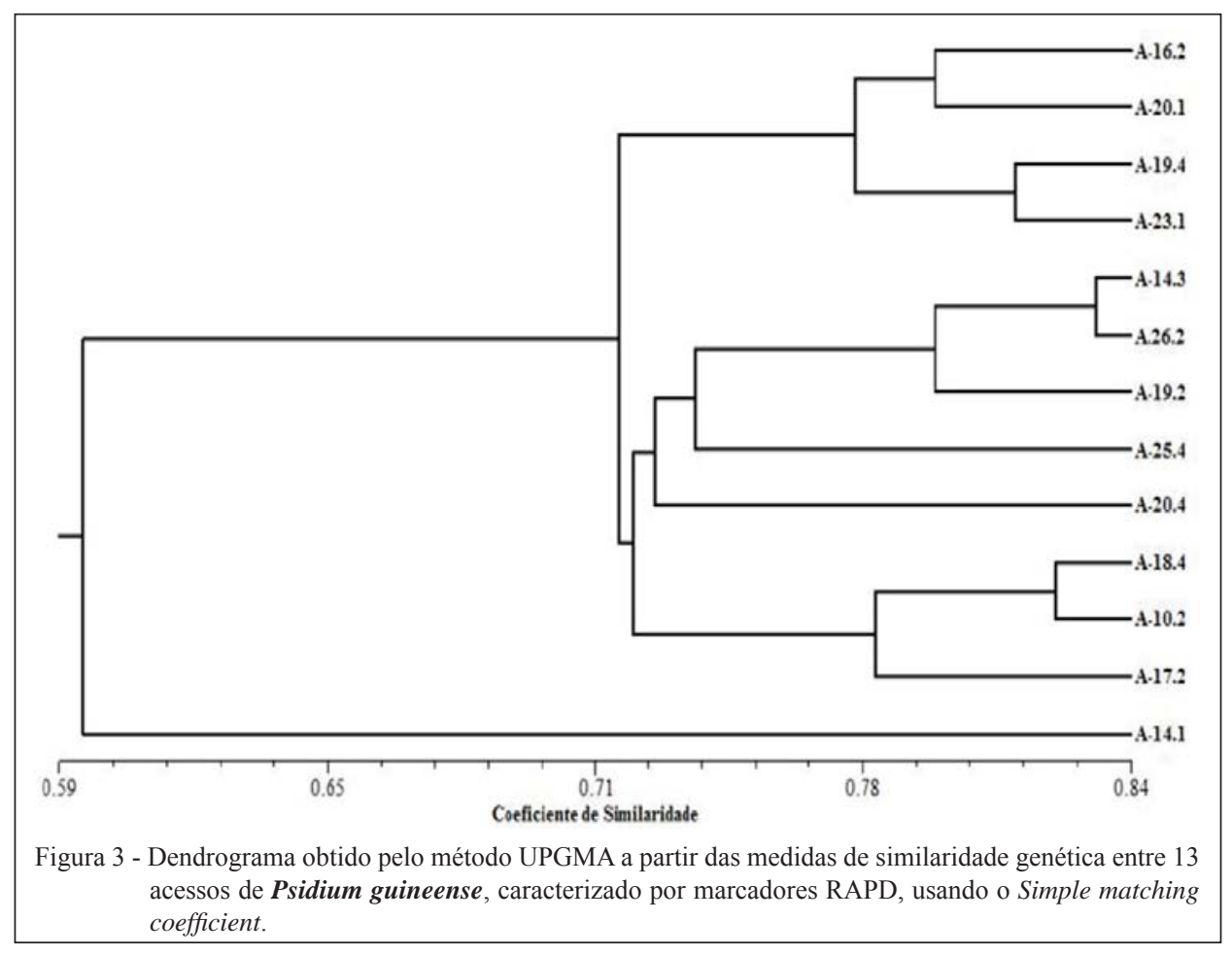

Ciência Rural, v.44, n.5, mai, 2014. 


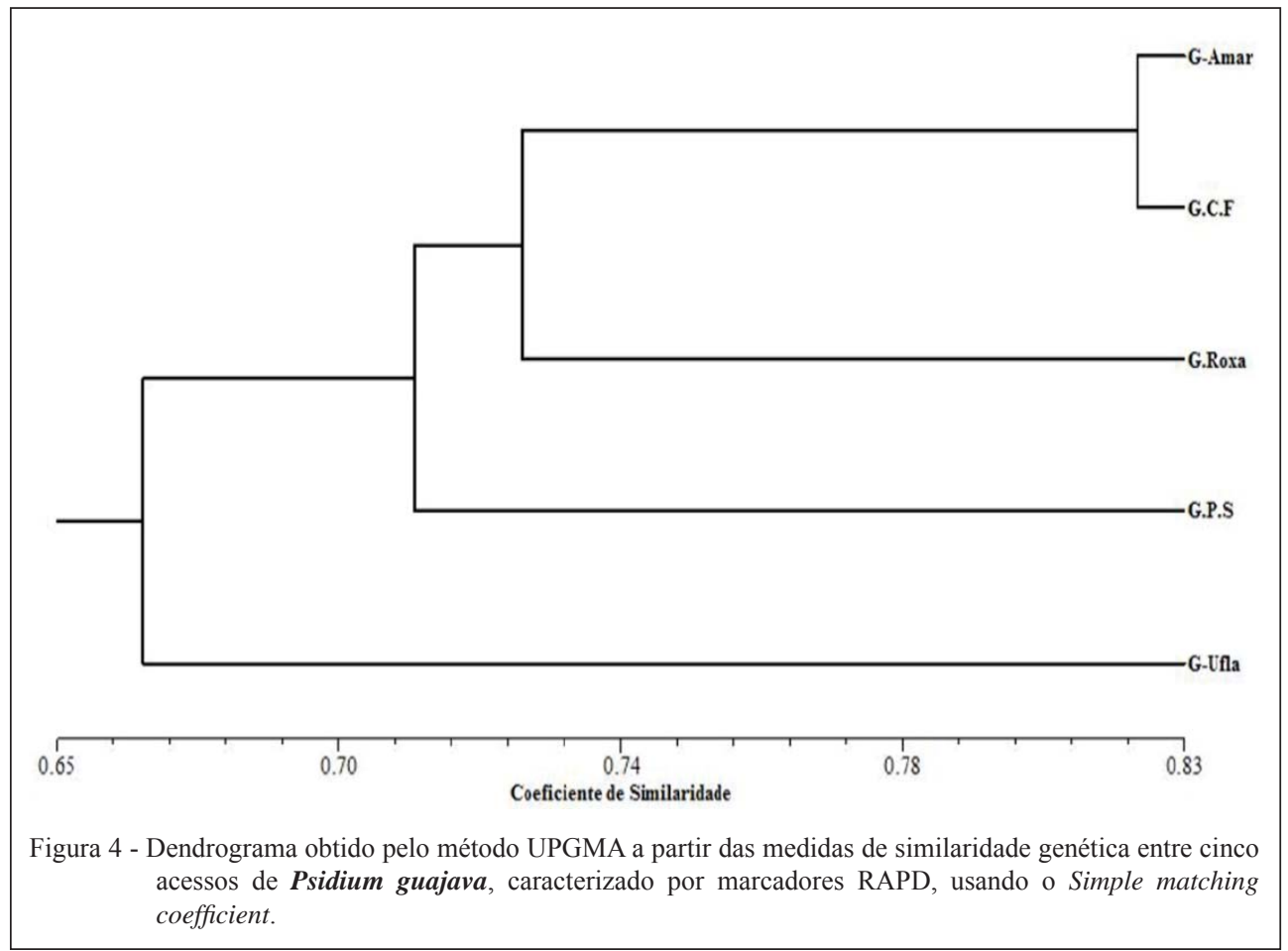

características em comum. Assim, os dados gerados poderão servir de norteamento para futuros trabalhos de compatibilidade entre os genótipos estudados, visando à obtenção de porta enxertos resistentes a $\boldsymbol{M}$. enterolobii para goiabeiras comerciais.

Os marcadores RAPD foram eficientes na identificação de polimorfismo de DNA em goiabeiras e araçazeiros, permitindo a aproximação de materiais com características de resistência ao nematoide e também pela sua origem. Apesar da identificação de acessos resistentes a $\boldsymbol{M}$. enterolobii em genótipos da espécie $\boldsymbol{P}$. cattleyanum, eles não se mostraram compatíveis, quanto à enxertia com a cultivar 'Pedro Sato'. Entretanto, testes de compatibilidade quanto à enxertia dos materiais já identificados como resistentes com outras cultivares de goiabeira comercial, como "Paluma", deverão ser efetuados, como também a busca de novas fontes de resistência no gênero Psidium deverão ser objetivos a serem alcançados em trabalhos futuros.

\section{CONCLUSÃO}

Os marcadores RAPD foram eficientes em agrupar os acessos de Psidium ssp, de acordo com a similaridade genética, e aproximaram os acessos considerados resistentes ao nematoide $M$. enterolobii.

Os iniciadores OPAH 03, OPAH 04, OPAH 11, OPAH 12, OPA 10, OPA 12, UBC 132, UBC135,
UBC153, BR65, PC11, PRIMER 1, PRIMER 3, PRIMER 6, PRIMER 7 e PRIMER 15 são indicados para estudos de diversidade em goiabeiras, utilizandose o marcador do tipo RAPD, já que apresentaram, em média, de 5,3 marcas polimórficas.

Os acessos Alu1, Alu2 e Alu3 apresentaram-se resistentes a $\boldsymbol{M}$. enterolobii, formando um subgrupo de Psidium sp, mostrando similaridade genética.

\section{REFERÊNCIAS}

ALVES, J.E.; BRENO, B.M. Requerimentos de polinização da goiabeira. Ciência Rural, v.37, n.5, p.1281-1286, 2007. Disponível em: $<$ http://www.redalyc.org/articulo.oa? $\mathrm{id}=33137510$. Acesso em: 18 dez. 2013. ISSN (Versão impressa): 0103-8478.

AREIAS, R.G B.M. et al. Similaridade genética de variedades crioulas de arroz, em função da morfologia, marcadores RAPD e acúmulo de proteínas nos grãos. Bragantia, v.65, n.1, p.19-28, 2006. Disponível em: <http://www.scielo.br/scielo. php?script $=$ sci arttext\&pid $=$ S0006-87052006000100004. Acesso em: 18 dez. 2013 . doi.org/10.1590/S0006-87052006000100004.

CARNEIRO, R.M.D.G. et al. Primeiro registro de Meloidogyne mayaguensis em goiabeira no Brasil. Nematologia Brasileira, v.25, n.2, p.223-228, 2001.

DOYLE, J.J.; DOYLE, J.L. Isolation of plant DNA from fresh tissue. Focus, v.1, p.13-15, 1990

FILHO. A.G. et al. Marcadores moleculares RAPD e descritores morfológicos na avaliação da diversidade genética de goiabeiras

Ciência Rural, v.44, n.5, mai, 2014. 
(Psidium guajava L.). Acta Scientiarum. Agronomy, Maringá, v.32, n.4, p.627-633, 2010. Disponível em: <http://www.scielo. br/scielo.php?pid $=$ S 1807-86212010000400009\&script $=$ sci arttext>. Acesso em: $18 \mathrm{dez}$. 2013. doi.org/10.4025/actasciagron. v32i4.4720.

GOMES. V.M. et al. Caracterização do estado nutricional de goiabeiras em declínio parasitadas por Meloidogyne mayaguensis. Nematologia Brasileira, v.32, n.2, p.154-160, 2008.

HARTMAN, H.T. et al. Plant propagation: principles and practices. 6.ed. New Jersey: Prentice Hall, 1997. 770p.

OLIVEIRA, M.S.P. et al. Diversidade genética entre acessos de açaizeiro baseada em marcadores RAPD. Ciência e Agrotecnologia, v.31, n.6, p.1645-1653, 2007. Disponível em: $<$ http://www.scielo.br/scielo.php?pid=S141370542007000600007 \&script=sci_arttext. Acesso em: 18 dez. 2013. doi.org/10.1590/ S1413-70542007000600007.

PADILLA-RAMÍREZ, J.S. et al. Caracterización de germoplasmas o bresaliente de guayabo de laregión Calvillo-Cañones, México. Revista Fitotecnia Mexicana, v.25, n.4, p.393-399, 2002. Disponível em: <http://www.scielo.org.mx/scielo.php?script=sci arttext\&pid=S0568-25172007000200009\&lng=es\&nrm=iso $>$. Acesso em: 18 dez. 2013.

ROHLF, F.J. Numerical taxonomy and multivariate analysis system. Version 2.11. New York: Applied Biostatistics, 2000. $134 \mathrm{p}$.

ROZANE, D.E.; COUTO, F.A.D'A. Cultura da goiabeira. Viçosa: UFV, 2003. 213p.
ROTILI, E.A. et al. Divergência genética em genótipos de milho, no estado do Tocantins. Revista Ciência Agronômica, v.43, n.3. p.70-76, 2012. Disponível em: <http://www.scielo. $\mathrm{br} / \mathrm{scielo.php}$ ?pid $=\mathrm{S} 1806-66902012000300014 \& \mathrm{script}=\mathrm{sci}$ arttext>. Acesso em: 18 dez. 2013. doi.org/10.1590/S180666902012000300014 .

SOUZA, R.M. et al. Manejo do nematoide das galhas da goiabeira em São João da Barra (RJ) e relato de novos hospedeiros. Nematologia Brasileira, v.30, n.1, p.165-169, 2006.

TORRES, G.R.C. et al. Meloidogyne mayaguensis em Psidium guajava no Rio Grande do Norte. Fitopatologia Brasileira, v.29, n.5, p.570, 2004. Disponível em: <http://www.scielo. br/scielo.php?pid=S0100-29452012000200027\& script $=$ sci arttext>. Acesso em: 18 dez. 2013. doi.org/10.1590/S010029452012000200027

UPADHYAY, M.K.; MURTY, B.R. Genetic divergence in relation to geographical distribution in pearl millet. Indian Journal of Genetics, v.30, p.704-715, 1970. Disponível em: <http://www. indianjournals.com/ijor.aspx?target $=$ ijor:ijgpb\&volume $=30 \&$ issue $=3 \&$ article $=028>$. Acesso em: 18 dez 2013 .

XAVIER, G.R. et al. Variabilidade genética em acessos de caupi analisada por meio de marcadores RAPD. Pesquisa Agropecuária Brasileira, v.40, n.4, p.353-359, 2005. Disponível em: <http:// www.scielo.br/pdf/pab/v40n4/24174.pdf>. Acesso em: $18 \mathrm{dez}$. 2013.

WILLIAMS, J.G.K. et al. Genetic analysis using RAPD markers. Methods in Enzymology, v.218, p.706-740, 1993. 